\section{EPA accused of conflict of interest over chemicals study}

Geoff Brumfiel, Washington

The Environmental Protection Agency

(EPA) is under fire from a watchdog group for accepting US\$2 million from a chemical-industry lobby organization to study the effects of pesticides and household chemicals on children.

The Environmental Working Group, a Washington-based non-profit body, says the funding represents a clear conflict of interest for the EPA. "The concern is that the regulated industry, which makes the products being tested, is buying access to the study's design, data and findings," says Jane Houlihan, the group's vicepresident for research.

But Paul Gilman, assistant administrator for research and development at the EPA, says the money comes with "no strings attached". He adds that the cash-strapped agency would be unable to do the research without the money. "Is ignorance better?" he asks.

The dispute concerns the Children's

Environmental Exposure Research Study, a three-year investigation that was originally designed to look at children's contact with commercial pesticides. When EPA scientists wanted to expand this to include chemicals commonly found around the home, they approached the American Chemistry Council (ACC), an industry lobby group representing 135 chemical manufacturers, according to Carol Henry, the council's vice-president for research.

Henry says that the ACC agreed to give an additional $\$ 2$ million to include chemicals found in everything from furniture coatings to cosmetics.

The ACC was willing to fund the study because it believes it will ultimately lead to sounder regulations, says Henry. "If you don't know how chemicals get to various individuals, you have to make a lot of assumptions under the regulatory procedures," she says.

Gilman adds that although the industry group will have a right to review the study 45 days before publication, it will have no influence on the research findings. "We're being very open and public about this process," he says.

But Houlihan remains concerned. “The EPA's research budget is over $\$ 500$ million a year, so you have to ask why the agency is relying on the lobbying arm of its own regulated industries for such a small sum of money in a study that could be critical to children's health protection," she says.

\title{
Standing room only signals US zeal for Earth imaging
}

\section{David Cyranoski}

Earth-science researchers in the United States are clamouring for a satellite system dedicated to observing the Earth's surface. Such a tool, they say, will transform studies of earthquakes, volcanoes, ice sheets and global land cover.

Organizers of a workshop to discuss the issue in Oxnard, California, last month were forced to turn people away. Some 350 researchers wanted to attend, 300 more than expected. Yet despite this growing scientific support, the price-tag of US\$450 million means that the project has so far failed to get off the ground.

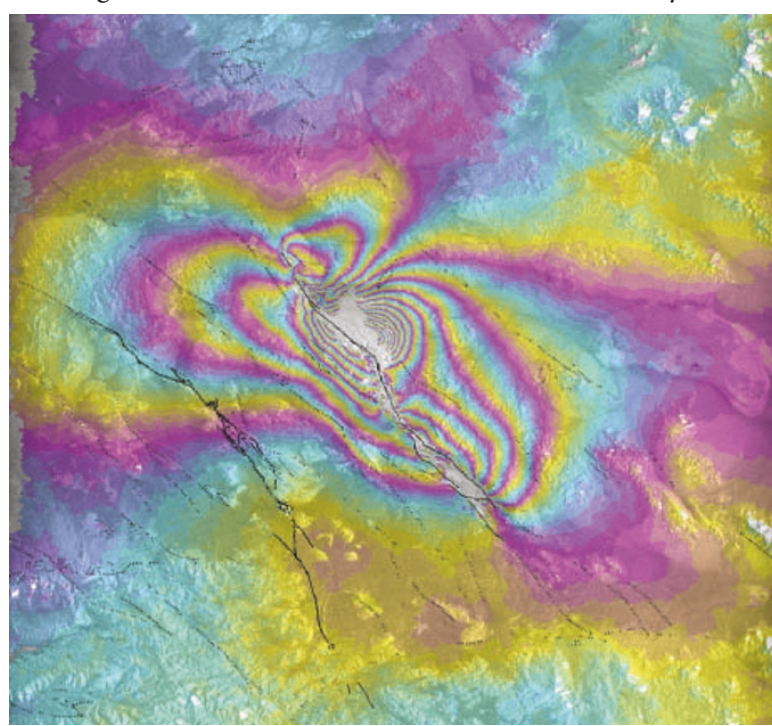

When the Earth moved: radar interferometry tracked ground displacements during California's 1999 Hector Mine earthquake. mapped.

and deflating much more frequently than previously thought. Massive ice sheets in Antarctica and Greenland have also been

But researchers say they cannot continue to rely on these satellites for InSAR data, as many were not optimally designed for radar imaging. Some have imprecise orbits, and so do not pass over the same spot of land on each revolution, making it difficult to measure change. Others use radar wavelengths that are unable to penetrate vegetation to image the ground beneath.

The lack of suitable satellites means that many events important to Earth scientists were not imaged by InSAR equipment. The area struck by California's 1994 Northridge earthquake, for example, was only imaged two months before and two years after the event, says Andrea Donnellan, a geophysicist at NASA's Jet Propulsion Laboratory in Pasadena, California. And the recent Parkfield earthquake (see Nature 431, $618 ; 2004)$ was not covered at all, she adds. "Missed opportunities are too many to mention," says Minster.

After ten years of requests and failed grant applications, the US InSAR hopefuls still do not have a dedicated satellite. Donnellan, who convened last month's workshop, hopes this will soon

The satellite-based technology that the researchers want is called InSAR, for interferometric synthetic aperture radar. These instruments bounce radar off the ground, creating a precise map of the surface, including information about the type of ground cover. Unlike global positioning systems, which can only take spot measurements of the location of receiver stations, InSARequipped satellites can image large continuous swaths of land.

"This is critical for studying natural hazards, polar ice sheets and large-scale land-cover changes resulting from climate change," says Jean-Bernard Minster, a geophysicist at Scripps Institution of Oceanography in La Jolla, California.

The few InSAR satellites launched by Japan, Europe and Canada have made some eye-opening discoveries in the past decade. Volcanoes thought to be dormant have been shown to be active, for example, and active volcanoes have been shown to be inflating change. The group is currently applying to the US space agency NASA for funding that could kick-start an InSAR programme. But the lengthy grant-approval process and the design and planning procedure mean that the earliest possible launch would be in 2010 .

Donnellan says that a dedicated InSAR system would quickly prove its worth, in much the same way that satellites dedicated to the oceans and atmosphere have vastly improved our understanding of climate and allowed us, for example, to predict El Niño events. "Atmospheric scientists demonstrated the value of spaceborne observations a little over 20 years ago, oceanographers about a decade ago, and when we have an InSAR mission, the same thing will occur for our field," she says.

In the meantime, other countries are continuing with their own InSAR projects. Japan plans to launch a $¥ 60$-billion (US\$600million) satellite next year, and China may launch its own as early as 2006. 